\title{
Organic carbon and environmental quality of riverine and off-shore sediments from the Gulf of Cádiz, Spain
}

\author{
J. A. González-Pérez • J. R. de Andrés • \\ L. Clemente • J. A. Martín • F. J. González-Vila
}

\begin{abstract}
Here we show that heavy metal geoaccumulation is apparent in the Tinto and Odiel estuary and, at a lower magnitude, in off-shore sediments. Values above probable effects level (PEL) are recorded for $\mathrm{As}, \mathrm{Cu}, \mathrm{Hg}$, $\mathrm{Pb}$ and $\mathrm{Zn}$ in the Tinto and Odiel estuary, for $\mathrm{As}$ and $\mathrm{Hg}$ in the associated off-shore sediments and for As in the Guadiana River. Significant correlations were found between total organic carbon (TOC) and $\mathrm{Cr}, \mathrm{Cu}, \mathrm{Ni}$ and $\mathrm{Zn}$ in the Tinto and Odiel estuary, and $\mathrm{Cr}, \mathrm{Cu}, \mathrm{Ni}, \mathrm{Pb}, \mathrm{Hg}$ and $\mathrm{As}$ in the Guadiana River. PCA analysis differentiated the three studied locations.
\end{abstract}

Keywords Huelva coast - Estuaries - Industrial wastes . Heavy metal pollution - Principal components analysis

\section{Introduction}

Concerns related to the management of aquatic ecosystems have traditionally focused on water quality. However, the importance of sediments in determining the fate and effects of a wide variety of contaminants is also relevant (Long et al. 1995).

Substances that are released into the environment, through natural processes or anthropogenically induced, may eventually enter aquatic ecosystems and deposit into bed sediments where contaminants may accumulate over time. Sediments become a long-term reservoir of chemicals to the aquatic environment and to organisms that thrive in these habitats. Hence, the exposure to certain substances, such as heavy metals present in sediments represents a potential hazard to the health of organisms including humans.

An effective assessment of the quality of a coastal environment requires a geochemical approach by studying not only the inputs and distribution of the different contaminants in the area, but also an understanding of the relationships between the concentration and the chemical form of particular chemicals in sediments. This will also provide valuable information about the effect that natural or human-related changes may have in the environment. In fact, these changes, which mainly affect sediment $\mathrm{pH}$, salinity and/or redox conditions, could lead to heavy metal remobilization from sediments increasing the potential risk of sedimentary-bound pollutants, i.e. dredging, civil works that affect water streams or new spills.

Determination of a sediment quality criteria (SQC) is a difficult task. Factors like local environmental conditions, as well as the partitioning of sediment contaminants into the dissolved phase and the adsorption of contaminants to particulate materials, determine the availability of contaminants to the biota (Kuang-Chung et al. 2001). However, under a practical point of view, it is possible to detect potential areas of sediment contamination and their environmental drift using a combination of methods based on levels of contamination in the area and toxicity. This would be of great assistance in formulating initial management decisions, i.e. prioritize degraded areas, required remediation, further site investigation, etc. 
This study focuses on heavy metal pollution and the relation with organic matter from the Tinto and Odiel estuary, one of the most polluted estuarine systems in Western Europe (Ruíz et al. 1998), Guadiana river and offshore associated sediments. A chemical numerical and a weight-of-evidence complementary approaches are used to contribute in assessing the quality of riverine and coastal environment in the Gulf of Cádiz, Southwest Spain.

\section{Materials and methods}

\section{Description of the area}

The South-western Iberian Peninsula comprises several estuarine systems in the confluence of the Atlantic Ocean and the Mediterranean Sea. The rivers in the area have provided a significant source of heavy metals by erosion of important ore deposits like Tinto and Odiel rivers that drains the Iberian Pyrite Belt, one of the largest sulfide deposits in the world. This is the area where the Copper and Bronze ages begun being mined for about 5,000 years BP consecutively by Iberians, Tartessans, Phoenicians and Romans cultures, introducing additional erosional products and acid mine wastes for thousands of years. A third source of pollution in the area is the industrial activity established during the late 1960s in Huelva, including a phosphate beneficiation plant, a black sand (magnetite and ilmenite) processing plant for the extraction of heavy metals, and a large paper mill, this is contributing huge volumes of pollutants to the Tinto and Odiel estuary (Nelson and Lamothe 1993; Davis et al. 2000).
Sampling, extraction and analysis of total organic carbon (TOC) and heavy metals

During May 1998, 105 surface composite samples were taken using a gravity sampler. To avoid contact with air, consequent oxidation and microbial contamination, the samples were kept isolated in the sampler tubes and stored frozen at $-18^{\circ} \mathrm{C}$. The distribution of the sediment samples, as well as the location of a $5 \mathrm{~m}$ depth borehole made to take a representative preanthropic background sample, is shown in Fig. 1.

TOC was estimated by elemental analysis of carbonate free samples, obtained after demineralization with $\mathrm{HCl}$ $1 \mathrm{~N}$, in an Eltra CS-2000 Carbon/Sulfur apparatus. Heavy metal analysis was done after multiacid digestion of ground and sieved $(<63 \mu \mathrm{m})$ of the $<2 \mathrm{~mm}$ sediment fraction. For $\mathrm{As}, \mathrm{Cr}, \mathrm{Cu}, \mathrm{Ni}, \mathrm{Pb}$ and $\mathrm{Zn}$ readings were done by optical emission spectrometry with inductively coupled plasma in a Thermo Jarrell Ash ICAP-61 equipment. Mercury determination was done following EPA's 7471 recommendation and detected by atomic absorption spectroscopy in a Varian Spectra 220-FS.

Sediment quality assessment

In order to evaluate if the values of the metals quantified in the sediments are the result of enrichment by external factors such are anthropogenic sources, Müller's geoaccumulation index $\left(I_{\text {geo }}\right)$ (Müller 1979) was calculated. This is a chemical numerical approach that compares the concentration of a substance in the sediment $\left(C_{n}\right)$ to the geochemical background for this substance $\left(B_{n}\right)$.
Fig. 1 Location of the study area showing sample distribution and background sample location

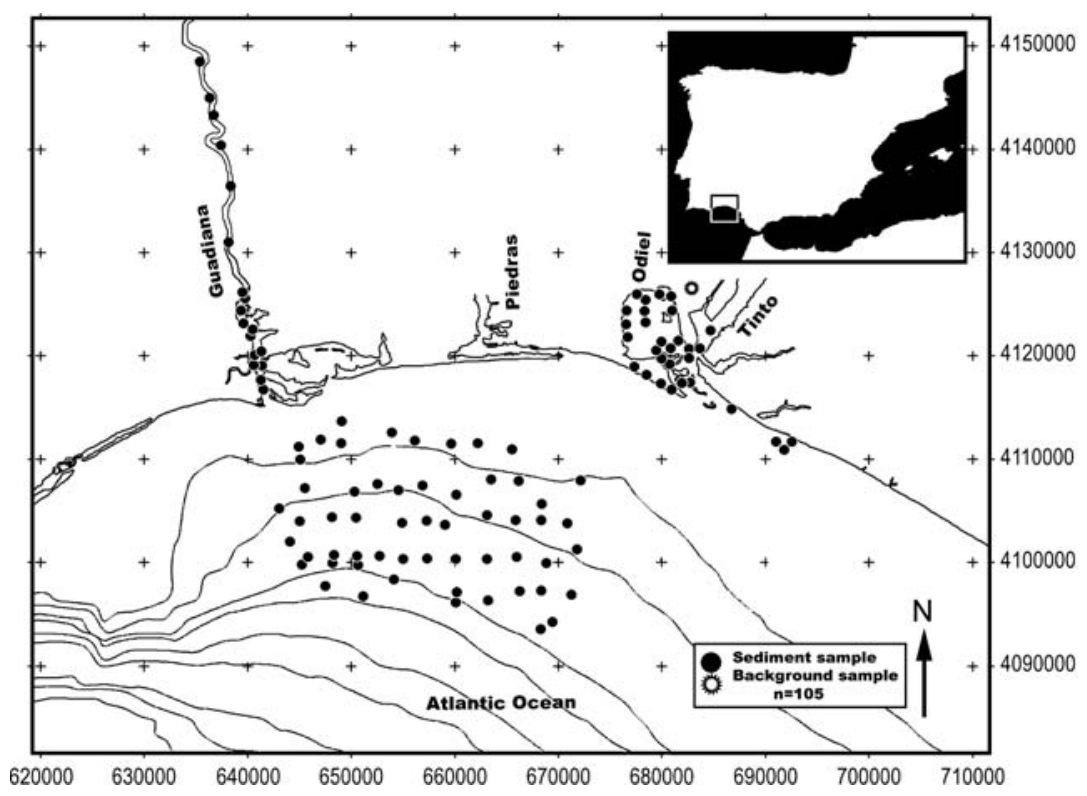


$I_{\text {geo }}=\log _{2} C_{n} / 1.5 B_{n}$

This index is a quantitative measure useful in assessing the metal enrichment of aquatic sediments, and consists of seven grades (0-6) that correspond with the contamination intensity (Förstner 1983), where the highest grade reflects 100 -fold enrichment above background value. The geo- chemical background values were measured from a sample taken in an undisturbed area in Huelva estuary at $5 \mathrm{~m}$ depth representing prehistoric heavy metal content for the area under study (Table 1).

The potential for biological effects of sediment-sorbed contaminants can be assessed using a weight-of-evidence approach (WEA). This assumes that the potential for

Table 1 Geochemical background (GB), threshold effect level (TEL), probable effects level (PEL) and average shale (AS) (mg/kg)

\begin{tabular}{lllllllr}
\hline & $\mathrm{As}$ & $\mathrm{Cr}$ & $\mathrm{Cu}$ & $\mathrm{Hg}$ & $\mathrm{Ni}$ & $\mathrm{Pb}$ & $\mathrm{Zn}$ \\
\hline $\mathrm{GB}^{\mathrm{a}}$ & 23.0 & 65.0 & 15.0 & 0.100 & 27 & 35.0 & 83 \\
$\mathrm{TEL}^{\mathrm{b}}$ & 5.9 & 37.3 & 35.7 & 0.174 & 18 & 35.0 & 123 \\
$\mathrm{PEL}^{\mathrm{b}}$ & 17.0 & 90.0 & 197.0 & 0.486 & 36 & 91.3 & 215 \\
$\mathrm{AS}^{\mathrm{c}}$ & 13 & 90 & 45 & 0.4 & 68 & 20 & 95 \\
\hline
\end{tabular}

a From a sample taken in Huelva metropolitan area at $15 \mathrm{~m}$ depth

b CCME (2001)

c Turekian and Wedepohl (1961)

Table 2 Heavy metal and total organic carbon (TOC), Müller's geoaccumulation index ( $\left.I_{\text {geo }}\right)$ and sediment quality from Tinto and Odiel estuary, Guadiana River and offshore surface sediment samples

\begin{tabular}{|c|c|c|c|c|c|c|c|c|c|c|c|c|}
\hline & \multicolumn{4}{|c|}{ Tinto and Odiel estuary $(n=30)$} & \multicolumn{4}{|c|}{ Guadiana River $(n=18)$} & \multicolumn{4}{|c|}{ Offshore $(n=57)$} \\
\hline & Min & Mean & $\operatorname{Max}$ & STD & Min & Mean & Max & STD & Min & Mean & Max & STD \\
\hline \multicolumn{13}{|c|}{ Heavy metal concentration $(\mathrm{mg} / \mathrm{kg})$ and TOC $(\%)$} \\
\hline As & 20 & 278 & 1156 & 257 & 20 & 39 & 78 & 19 & 21 & 38 & 58 & 7 \\
\hline $\mathrm{Cr}$ & 8 & 66 & 119 & 33 & 32 & 50 & 104 & 18 & 13 & 84 & 204 & 29 \\
\hline $\mathrm{Cu}$ & 20 & 1051 & 3304 & 885 & 11 & 27 & 67 & 17 & 5 & 70 & 197 & 34 \\
\hline $\mathrm{Hg}$ & 0.1 & 3 & 17 & 4 & 0.1 & 0.1 & 0.3 & 0.06 & 0.1 & 0.6 & 1 & 0.3 \\
\hline $\mathrm{Ni}$ & 1 & 30 & 55 & 18 & 19 & 27 & 49 & 8 & 1 & 29 & 46 & 12 \\
\hline $\mathrm{Pb}$ & 19 & 523 & 2873 & 643 & 19 & 27 & 39 & 6 & 10 & 76 & 263 & 37 \\
\hline $\mathrm{Zn}$ & 61 & 1574 & 3300 & 1074 & 115 & 150 & 303 & 42 & 17 & 194 & 360 & 69 \\
\hline $\mathrm{TOC}^{\mathrm{a}}$ & 0.42 & 1.32 & 2.06 & 0.52 & 0.03 & 0.59 & 1.68 & 0.54 & 0.64 & 1.99 & 2.71 & 0.49 \\
\hline \multicolumn{13}{|c|}{ Müller's geoaccumulation index $\left(I_{\text {geo }}\right)$} \\
\hline As & -0.8 & 2.3 & 5.1 & 1.7 & -0.8 & 0.0 & 1.2 & 0.7 & -0.7 & 0.1 & 0.7 & 0.3 \\
\hline $\mathrm{Cr}$ & -3.6 & -0.9 & 0.3 & 1.2 & -1.6 & -1.0 & 0.1 & 0.4 & -2.9 & -0.3 & 1.1 & 0.5 \\
\hline $\mathrm{Cu}$ & -0.2 & 4.6 & 7.2 & 2.3 & -1.0 & 0.0 & 1.6 & 0.9 & -2.2 & 1.4 & 3.1 & 1.0 \\
\hline $\mathrm{Hg}$ & -0.6 & 3.0 & 6.8 & 2.1 & -0.6 & -0.3 & 1.0 & 0.5 & -0.6 & 1.6 & 2.7 & 1.0 \\
\hline $\mathrm{Ni}$ & -5.3 & -1.2 & 0.4 & 2.1 & -1.1 & -0.7 & 0.3 & 0.4 & -5.3 & -0.9 & 0.2 & 1.6 \\
\hline $\mathrm{Pb}$ & -1.5 & 2.3 & 5.8 & 2.0 & -1.5 & -1.0 & -0.4 & 0.3 & -2.4 & 0.4 & 2.3 & 0.8 \\
\hline $\mathrm{Zn}$ & -1.0 & 3.1 & 4.7 & 1.6 & -0.1 & 0.2 & 1.3 & 0.3 & -2.9 & 0.5 & 1.5 & 0.8 \\
\hline \multicolumn{13}{|c|}{ Sediment quality (times the PEL value) } \\
\hline As & 1.2 & 16.4 & 68.0 & 15.1 & 1.2 & 2.3 & 4.6 & 1.1 & 1.2 & 2.2 & 3.4 & 0.4 \\
\hline $\mathrm{Cr}$ & 0.1 & 0.7 & 1.3 & 0.4 & 0.4 & 0.6 & 1.2 & 0.2 & 0.1 & 0.9 & 2.3 & 0.3 \\
\hline $\mathrm{Cu}$ & 4.5 & 5.3 & 16.8 & 4.5 & 0.1 & 0.1 & 0.3 & 0.1 & 0.0 & 0.4 & 1.0 & 0.2 \\
\hline $\mathrm{Hg}$ & 0.0 & 5.5 & 35.0 & 8.0 & 0.2 & 0.3 & 0.6 & 0.1 & 0.0 & 1.1 & 2.1 & 0.6 \\
\hline $\mathrm{Ni}$ & 0.0 & 0.8 & 1.5 & 0.5 & 0.5 & 0.7 & 1.4 & 0.2 & 0.0 & 0.8 & 1.3 & 0.3 \\
\hline $\mathrm{Pb}$ & 0.2 & 5.7 & 31.5 & 7.0 & 0.2 & 0.3 & 0.4 & 0.1 & 0.1 & 0.8 & 2.9 & 0.4 \\
\hline $\mathrm{Zn}$ & 0.3 & 7.3 & 15.3 & 5.0 & 0.5 & 0.7 & 1.4 & 0.2 & 0.1 & 0.9 & 1.7 & 0.3 \\
\hline
\end{tabular}


observing toxicity resulting from exposure to a chemical increases with increasing concentration of the chemical in the sediment (Long et al. 1995). Therefore, matching sediment chemistry and biological effects data (co-occurrence data) are collected and evaluated to establish associations between pollutant concentration and the adverse biological effect. Then the data is incorporated into a database (Biological Effects Database for Sediments; BEDS) from which threshold effects levels (TELs) and probable effects levels (PELs) for each chemical can be calculated. The TEL value represents the contaminant concentration in the sediment below which adverse biological effects are expected to occur rarely; PEL value defines the concentration above which adverse effects are expected to occur frequently. TEL and PEL values used for this study, were those derived from BEDS database and are shown in Table 1 (CCME 2001).
Statistical analysis

The relationship between heavy metals and TOC content was analysed by bivariate analysis by measuring the linear association between all pairs of variables with a two-tailed Pearson's correlation coefficient. Principal components analysis (PCA) was performed on the geoaccumulated $\left(I_{\text {geo }}\right)$ data $\left(I_{\text {geo }}\right.$ values) for sediments and elements. Varimax rotation method was applied for better separation of cases on two axes plots.

\section{Results and discussion}

Prehistoric values obtained and used as geochemical background were comparable to those previously reported for the area (Ruíz et al. 1998; Santos Bermejo et al. 2003),

Table 3 Bivariate regression analysis, Pearson's correlation coefficient (R)

\begin{tabular}{|c|c|c|c|c|c|c|c|}
\hline & As & $\mathrm{Cr}$ & $\mathrm{Cu}$ & $\mathrm{Ni}$ & $\mathrm{Pb}$ & $\mathrm{Zn}$ & $\mathrm{Hg}$ \\
\hline $\mathrm{Cr}$ & $0.188 \mathrm{~ns}$ & & & & & All samples & \\
\hline $\mathrm{Cu}$ & $0.881 * *$ & $0.207^{*}$ & & & & & \\
\hline $\mathrm{Ni}$ & $0.292 * *$ & $0.309 * *$ & $0.352 * *$ & & & & \\
\hline $\mathrm{P} *$ & $0.935^{* *}$ & $0.198 *$ & $0.814 * *$ & $0.257 * *$ & & & \\
\hline $\mathrm{Zn}$ & $0.822 * *$ & $0.173 \mathrm{~ns}$ & $0.882 * *$ & $0.430 * *$ & $0.707 * *$ & & \\
\hline $\mathrm{Hg}$ & $0.899 * *$ & $0.203 *$ & $0.777 * *$ & $0.254 *$ & $0.968 * *$ & $0.625 * *$ & \\
\hline TOC & $-0.039 \mathrm{~ns}$ & $0.477 * *$ & $0.036 \mathrm{~ns}$ & $0.262 *$ & $0.012 \mathrm{~ns}$ & $0.048 \mathrm{~ns}$ & $0.035 \mathrm{~ns}$ \\
\hline $\mathrm{Cr}$ & $0.657 * *$ & & & & & $\begin{array}{l}\text { Tinto and Odiel } \\
\text { estuary }\end{array}$ & \\
\hline $\mathrm{Cu}$ & $0.798 * *$ & $0.761 * *$ & & & & & \\
\hline $\mathrm{Ni}$ & $0.497 * *$ & $0.929 * *$ & $0.628 * *$ & & & & \\
\hline $\mathrm{P} *$ & $0.920 * *$ & $0.576 * *$ & $0.737 * *$ & $0.359 \mathrm{~ns}$ & & & \\
\hline $\mathrm{Zn}$ & $0.686^{* *}$ & $0.782 * *$ & $0.760 * *$ & $0.830 * *$ & $0.557 * *$ & & \\
\hline $\mathrm{Hg}$ & $0.894 * *$ & $0.538 * *$ & $0.719 * *$ & $0.269 \mathrm{~ns}$ & $0.966 * *$ & $0.466^{*}$ & \\
\hline TOC & $0.378 \mathrm{~ns}$ & $0.759 * *$ & $0.573 *$ & $0.789 * *$ & $0.260 \mathrm{~ns}$ & $0.650 * *$ & $0.189 \mathrm{~ns}$ \\
\hline $\mathrm{Cr}$ & $-0.244 \mathrm{~ns}$ & & & & & Guadiana River & \\
\hline $\mathrm{Cu}$ & $-0.207 \mathrm{~ns}$ & $0.837 * *$ & & & & & \\
\hline $\mathrm{Ni}$ & $-0.073 \mathrm{~ns}$ & $0.967 * *$ & $0.866^{* *}$ & & & & \\
\hline $\mathrm{P}^{*}$ & $-0.100 \mathrm{~ns}$ & $0.738 * *$ & $0.725 * *$ & $0.697 * *$ & & & \\
\hline $\mathrm{Zn}$ & $0.222 \mathrm{~ns}$ & $0.377 \mathrm{~ns}$ & $0.699 * *$ & $0.467 \mathrm{~ns}$ & $0.498^{*}$ & & \\
\hline $\mathrm{Hg}$ & $-0.347 \mathrm{~ns}$ & $0.284 \mathrm{~ns}$ & $0.179 \mathrm{~ns}$ & $0.124 \mathrm{~ns}$ & $0.486 *$ & $-0.136 \mathrm{~ns}$ & \\
\hline TOC & $-0.528^{*}$ & $0.822 * *$ & $0.808 * *$ & $0.753 * *$ & $0.651 * *$ & $0.289 \mathrm{~ns}$ & $0.484 *$ \\
\hline $\mathrm{Cr}$ & $-0.052 \mathrm{~ns}$ & & & & & Offshore & \\
\hline $\mathrm{Cu}$ & $0.619 * *$ & $-0.284 *$ & & & & & \\
\hline $\mathrm{Ni}$ & $0.528 * *$ & $-0.277^{*}$ & $0.620 * *$ & & & & \\
\hline $\mathrm{P}^{*}$ & $0.284^{*}$ & $-0.326^{*}$ & $0.636^{* *}$ & $0.519 * *$ & & & \\
\hline $\mathrm{Zn}$ & $0.599 * *$ & $-0.430 * *$ & $0.918 * *$ & $0.771 * *$ & $0.705 * *$ & & \\
\hline $\mathrm{Hg}$ & $0.451 * *$ & $-0.426 * *$ & $0.755^{* *}$ & $0.551 * *$ & $0.531 * *$ & $0.791 * *$ & \\
\hline TOC & $0.035 \mathrm{~ns}$ & $-0.171 \mathrm{~ns}$ & $0.079 \mathrm{~ns}$ & $-0.074 \mathrm{~ns}$ & $0.135 \mathrm{~ns}$ & $0.129 \mathrm{~ns}$ & $-0.042 \mathrm{~ns}$ \\
\hline
\end{tabular}

\footnotetext{
** Correlation is significant at the 0.01 level. * Correlation is significant at the 0.05 level. ns Correlation is not significant (two-tailed)
} 
with remarkable high arsenic content $(23 \mathrm{mg} / \mathrm{kg})$, almost $78 \%$ higher than the average content in the shale (Table 1). The heavy metal content in the sediments from the three locations is shown in Table 2. Geoaccumulation is apparent for $\mathrm{As}, \mathrm{Cu}, \mathrm{Hg}, \mathrm{Pb}$ and $\mathrm{Zn}$ in the Huelva area of Tinto and Odiel estuary. Similar $\mathrm{Cu}, \mathrm{Pb}$ and $\mathrm{Zn}$ geoaccumulation values for this area have been reported using the same methodology (Santos Bermejo et al. 2003). A similar pattern for $I_{\text {geo }}$, although with lower magnitude, is observed in the off-shore sediments. No geoaccumulation is observed in the Guadiana River.

The sediment quality in the area as measured with the WEA method shows high values for As in the three locations studied, but we have to consider that prehistoric value for this element is in the order of 1.4 times the PEL. In addition, higher values than the PEL are recorded for $\mathrm{Cu}, \mathrm{Hg}, \mathrm{Pb}$ and $\mathrm{Zn}$ in the Tinto and Odiel estuary, for $\mathrm{Hg}$ in the associated off-shore sediments and only for As in the Guadiana River. This approach to establish sediment quality has to be taken with caution mainly because the knowledge about bioavailability of sediment-associated contaminants, synergies between contaminants and other toxicological issues such as chronic toxicity and adaptations is limited.

With relation to the organic carbon significant positive correlations were found between TOC and $\mathrm{Cr}, \mathrm{Cu}, \mathrm{Ni}$ and $\mathrm{Zn}$ in the Tinto and Odiel estuary, and with $\mathrm{Cr}, \mathrm{Cu}, \mathrm{Ni}, \mathrm{Pb}$ and $\mathrm{Hg}$ and negative with As in the Guadiana River. No correlation was observed between TOC and heavy metals content in offshore samples that, in turn, showed a strong correlation between pairs of metals with the only exception of $\mathrm{Cr}$ vs As (Table 3). This may indicate that heavy metals in riverine and estuarine sediments are forming complexes with the organic matter due to adsorption processes in a low salinity environment, whereas in off-shore sediments heavy metals are associated preferably to the sediment mineral matrix. Highly significant positive correlation is also observed between As and all other metals in the samples from the Tinto and Odiel estuary. No correlation is observed in the Guadiana River, where this relation is showing a negative tendency. It is possible that all elements studied share common sources in the Tinto and
Fig. 2 Principal components analysis (PCA) for (a) $I_{\text {geo }}$ values for elements (b) $I_{\text {geo }}$ values for samples. (open circle Tinto and Odiel estuary; open triangle Guadiana River; filled circle Off-shore sediments)

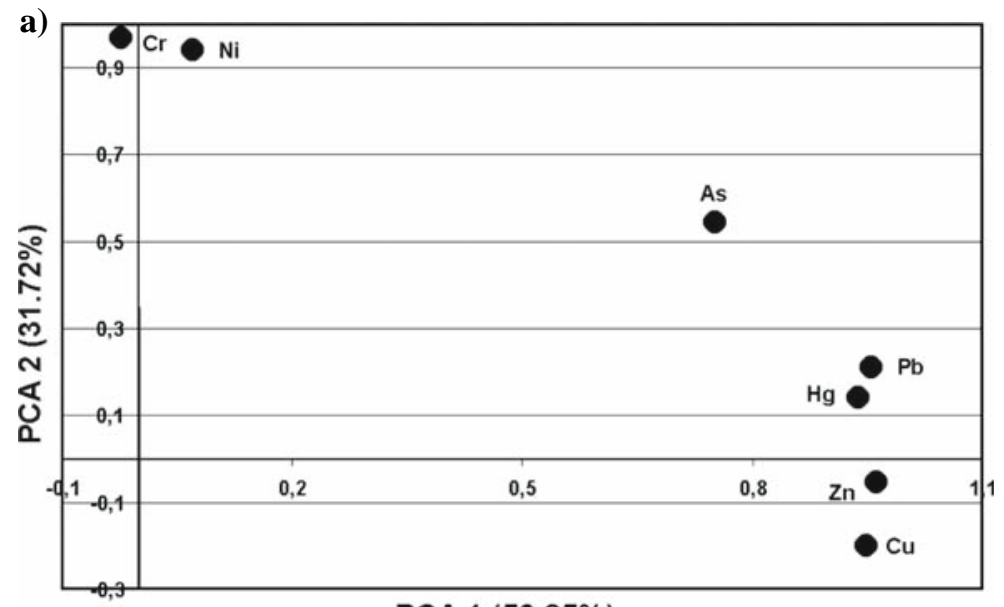

PCA $1(59.85 \%)$

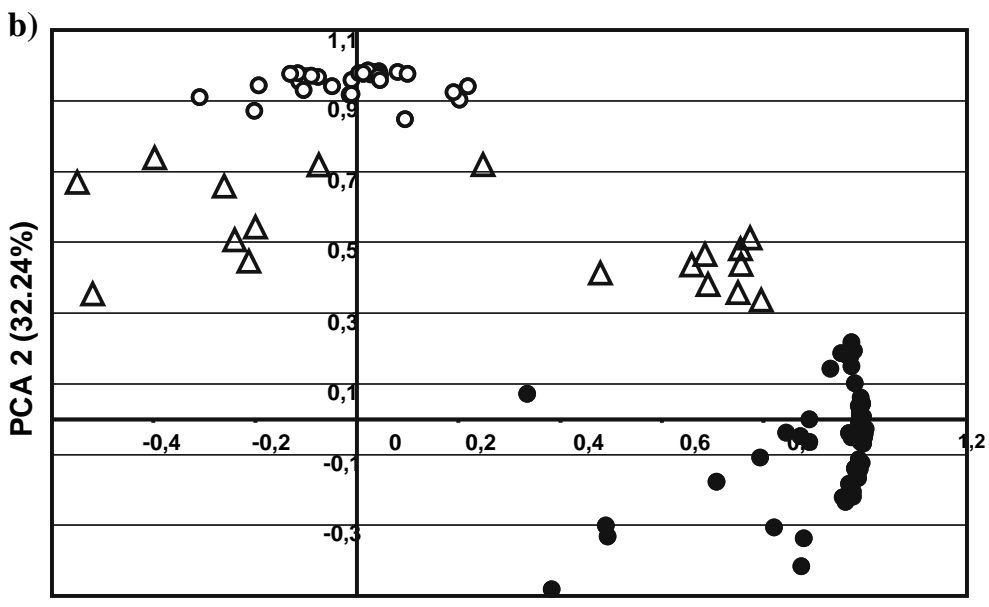

PCA 1 (53.15\%) 
Odiel estuarine system, or, most probable, that a major source does exist (incoming rivers that drains the Iberian Pyrite Belt) with metals sharing a similar transport and sedimentation pattern.

PCA performed on elements (Fig. 2a) differentiated two groups of elements: $\mathrm{Cr}$ and $\mathrm{Ni}$ are clustered in one group indicating a similar pattern of geoaccumulation, a second cluster is formed by $\mathrm{As}, \mathrm{Pb}, \mathrm{Hg}, \mathrm{Zn}$ and $\mathrm{Cu}$. In the PCS performed on the sediment samples (Fig. 2b), the two first axes explained $85.39 \%$ of the associated variation. Good discrimination is observed between the samples and their origin, with three discrete groups corresponding to the three locations. The discrimination observed may be in relation with a marine influence on samples plotted towards the right low part of the chart and preferential geoaccumulation of $\mathrm{Cr}$ and $\mathrm{Ni}$ with organic matter towards the opposite corner of the PCA plot.

As previously reported, acid mine drainage and the presence of sulphide minerals are likely to be the major sources of $\mathrm{Cu}, \mathrm{Hg}, \mathrm{Ni}, \mathrm{Zn}$ and $\mathrm{Pb}$ in the surface sediments from the Tinto and Odiel estuary. Phosphate fertilizer industry and dumping of phosphogypsum in the estuarine zone may also represent an important source for heavy metals like $\mathrm{Hg}$ and As to the Tinto and Odiel estuary (Grande et al. 1999; Kuang-Chung et al. 2001; ElbazPoulichet et al. 2001; Ruíz 2001). A probable geoaccumulation process, whereas not the only possible one (see Galán et al. 2003; Santos Bermejo et al. 2003), would be the formation of organomineral complexes in this highly anthropisized area with large inputs of organic matter from nearby urban areas and from the paper pulp industry. This may be causing the precipitation and accumulation of heavy metals with organic matter, being more apparent in the Tinto and Odiel estuary with a higher load of metals, a closer geomorphology and a more favouring hydrodynamic environment for local deposition and accumulation than in the Guadiana River.

\section{References}

CCME (2001) Canadian sediment quality guidelines for the protection of aquatic life: Summary tables. Updated in: Canadian Environmental Quality Guidelines, 1999, The Canadian Council of Ministers of the Environment (CCME), Winnipeg, Canada

Davis RA, Welty AT, Borrego J, Morales JA, Pendón JA, Ryan JG (2000) Rio Tinto estuary (Spain): 5,000 years of pollution. Environ Geol 39:1107-1116

Elbaz-Poulichet F, Braungardt C, Achterberg E, Morley N, Cossa D, Beckers JM, Nomérange P, Cruzado A, Leblanc M (2001) Metal biogeochemistry in the Tinto-Odiel rivers (Southern Spain) and the Gulf of Cádiz: a synthesis of the results of TOROS project. Cont Shelf Res 21:1961-1973

Förstner U (1983) Metal pollution in the aquatic environment. Springer, Berlin

Galán E, Gómez-Ariza JL, González I, Fernández-Caliani JC, Morales E, Giráldez I (2003) Heavy metal partitioning in river sediments severely polluted by acid mine drainage in the Iberian Pyrite Belt. Appl Geochem 18:409-421

Grande JA, Borrego J, Morales JA (1999) A study of heavy metal pollution in the Tinto-Odiel estuary in Southwestern Spain using factor analysis. Environ Geol 39:1095-1101

Kuang-Chung Y, Li-Jyur T, Shih-Hsiung C, Shien-Tsong H (2001) Correlation analyses on binding behavior of heavy metals with sediment matrices. Water Res 35:2417-2428

Long ER, MacDonald DD, Smith SL, Calder FD (1995) Incidence of adverse biological effects within ranges of chemical concentrations in marine and estuarine sediments. Environ Manage 19:81-97

Müller G (1979) Schwermetalle in den sedimenten des RheinsVeränderungen seit 1971. Umschau 79:107-126

Nelson CH, Lamothe PJ (1993) Heavy metals anomalies in the Tinto and Odiel River estuary system, Spain. Estuaries 16:496-511

Ruíz F (2001) Trace metals in estuarine sediments from Southwestern Spanish coast. Mar Pollut Bull 42:482-490

Ruíz F, González-Regalado ML, Borrego J, Morales JA, Pendón JG, Muñóz JM (1998) Stratigraphic séquense, elemental concentrations and heavy metal pollution in Holocene sediments from the Tinto-Odiel Estuary, Southwestern Spain. Environ Geol 34:270 278

Santos Bermejo JC, Beltrán R., Gómez Ariza JL (2003) Spatial variations of heavy metals contamination in sediments from Odiel river (Southwest Spain). Environment Int 29:69-77

Turekian KK, Wedepohl KH (1961) Distribution of the elements in some major units of the Earth's crust. Geol Soc Am Bull 72:175-191 